\title{
THE EFFECT OF PRODUCTS ATTRIBUTES CUSTOMER SATISFACTION ON BRAND LOYALTY IN THE ELECTRONIC APPLIANCES INDUSTRY: CASE OF JORDAN
}

\author{
Nemer Aburumman ${ }^{1^{*}}$, Asisa Nieto ${ }^{2}$ \\ ${ }^{1}$ Doctoral School of Management and Business, University of Debrecen, Debrecen, \\ Hungary \\ ${ }^{2}$ Faculty of Humanities, Pablo de Olavide University, Sevilla, Spain \\ nemer.aburumman@econ.unideb.hu \\ asisanieto@gmail.com
}

\begin{abstract}
This paper shows an analysis of products attributes, customer satisfaction and brand loyalty in the electronic appliances sector. The main goal of the research is to determine the influence of a product's physical and service-related attributes on customer satisfaction and eventually on brand loyalty. In particular, the objective of this paper is to answer the following question: if the attributes of a product influence in a customer satisfaction and in that way on a brand's loyalty? We defined Customer satisfaction as the satisfaction of customers with any products. Therefore, the satisfaction was examined through a survey using questionnaires. The population included all customers of two of the branches from SmartBuy (one of the biggest companies in the IT sector in Jordan) in Amman. We designed the questionnaire and distributed it randomly to the respondents in two branches of the mentioned company. The questionnaire conducted was distributed to 150 respondents; we excluded 43 questionnaires from the analysis due to the incomplete data. So (107) questionnaires were valid for the study. The results show a correlation between the main factors, but more extensive researches in terms of the number of companies used in sampling must be conducted to verify this relation due to more factors mostly statistically insignificant.
\end{abstract}

Keywords: Products Attributes, Customer Satisfaction, Jordan, Brand Loyalty, IT Management.

JEL classification: M30, M15.

\section{Introduction}

Organizations are becoming more aware of the importance of customer satisfaction influence on brand loyalty and therefore businesses are focusing on improving this relation in order to regulate consumer's purchasing intentions and behaviours and upholding growth in vastly competitive environments.

The concept "brand loyalty" hugely affects the performance of businesses and reimbursements for any business; this research tries to achieve the following objectives:

- Explore the factors that may influence the brand loyalty.

- Analyse the relationship between the two variables customer's satisfaction and brand loyalty.

- Study the role of a product's attributes and its influence on customer satisfaction and brand loyalty.

We can see the customer satisfaction as "one of the most crucial ways to make the marketing performance considerable and sustained" (Piercy, 1995:25) and one of the main

\footnotetext{
* Corresponding author: Nemer, Aburumman
} 
concepts in marketing (Fournier and Glick, 1999). In the earlier literature, the models created to study brand loyalty and customer satisfaction frequently studied consumers buying packaged goods but not durable goods and so we aim through this research to explore the experiences of customer satisfaction's and brand loyalty in the situation of (SmartBuy) a company in electronic appliances sector in Amman.

The attributes of a product have a huge impact on the satisfaction of its consumers and on their intentions to buy; therefore, the approach of an organization towards managing those attributes will either affect the mission of the organization positively or negatively, satisfaction wise and creating loyalty towards the brand wise.

\section{Literature Review}

As Abdul Ghafoor and Asad-ur (2014) mentioned, the customer satisfaction and brand loyalty has become a phenomenon and considered a dynamic matter for which the business firms are so sensitive. The key reason behind its development is to see the relation between customer satisfaction and brand loyalty and this is because the customer with more loyalty to the firm and as longer as the customer is retained, will conclude to increase the selling and profits the business might generate as well (Edvardsson et al., 2002). The more benefits of enhanced brand loyalty could happen from holding current customers alongside attracting to bring new customers. These benefits might, in turn, score in increasing the sales and profitability for the organizations well. Firstly, the loyal customers are more likely to stick to their sellers or service providers on a long turn and at the same time they are more likely to cross-purchase (Oliver, 1997; Reichheld, 1996). Secondly, previous studies commonly support the assumption that say attracting new customers is always more expensive than holding the current existing ones (Blattberg and Deighton, 1996; Fites, 1996).

Therefore, this paper explores the brand-loyalty relations at more enduring levels of a product's physical and value-related attributes that participants experience in conditions outside the classrooms and laboratory.

\subsection{Customer Satisfaction}

Kotler defined customer satisfaction as "The feelings of a person's pleasure or disappointment came from comparing the outcome (or a product's perceived performance) in relation to his or her expectations" (Kotler, 2000:101). Alongside, Oliver defines customer satisfaction as a "decision resulting after a consumption experience - it is the consumer's decision that a product providing (or is provided) an enjoyable level of consumption-related fulfilment "(Oliver, 1997). Moreover, customer satisfaction can be defined as consumer ratings of specific attributes (Gómez et al., 2004). Many scholars studied the effect of other factors on the satisfaction of the consumer such as the service efficiency and company's marketing policies, but in our study we'll omit such factors and only focus on the product's attributes and their influence on customer satisfaction and subsequently the brand loyalty of consumers (Pakurár et al., 2019).

\subsection{Brand Loyalty}

Kotler et al. (2000) defined the brand loyalty as the faithfulness that a consumer shows towards a specific brand; and this customer showed this faithfulness through repeating the purchases over time and also other positive behaviours may come such as telling other people about this brand (word of mouth advocacy), regardless of the pressures and promotions generated by the other competing brands; (Kotler, et al., 2008). And one of the popular definitions for the brand loyalty is" a function of psychological processes that biased behavioural response (purchase) expressed with time by some decision-making unit with respect to one or more alternative brands out of a set of brands" (Jacoby 1971: 25). Brand 
loyalty depends on the customer's arousing responses to the usage of a product or service which is defined as customer satisfaction (Oliver, 1981). Hence, brand loyalty can be one of the main ways the consumers can express their satisfaction with the product or service received (Delgado-Ballester and Munuera-Aleman 2001). The previous definitions illustrate that brand loyalty is expressed through many factors; most importantly repeated purchases of a specific brand while being offered a huge evoked set of competing or alternative brands.

\subsection{Customer Satisfaction and Brand Loyalty}

General satisfaction was combined as a main factor of purchase intentions with reference to brand loyalty (Spreng et al., 1996). From Bloemer and Kasper's (1995) perspective, customer loyalty is one of the significant trails with which customer satisfaction about product or services received is expressed. Thus, this proves that the previous studies of scholars indicate the important role that customer's satisfaction plays in increasing purchase and repurchase intentions of a customer and how it is considered to be an important determinant of customer loyalty towards a brand. The more frequent a consumer purchases a specific brand, the more satisfied he/she is with the product itself and the attributes it has to offer to them.

\subsection{Theoretical Framework}

Most studies confirm the positive relationship between products attributes and brand loyalty with job satisfaction playing a mediating effect. For example, Dhurup, et al (2014) found that significant positive relationships between packaging, price, brand awareness and brand loyalty, which means tacit their significant predictive effect on brand loyalty. Another example is the study of the scholars Shaharudin, et al (2010). showed that the brand loyalty influenced positively from the extrinsic attribute or in other words, product quality based on the perceived quality.

Finally, the theoretical framework below is to ascertain the previous relations mentioned before under a company in the electronic appliances industry in Jordan, moreover, this study will investigate two variables of product's attributes that are: physical attributes of a product and value-related attributes of a product, therefore, according to what we mentioned before we developed the following framework:

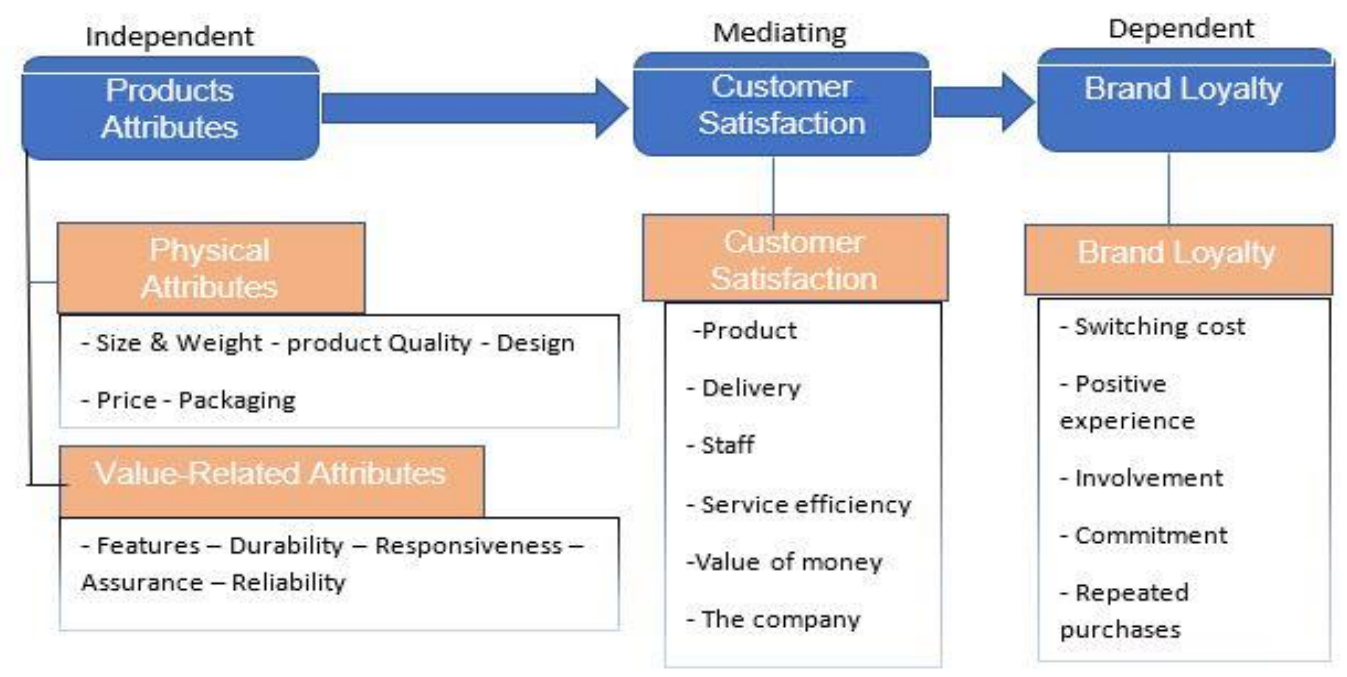

Figure 1: Proposed framework

Source: Authors own development 


\title{
2.5. Research Hypothesis
}

In this paper, we will examine how the independent variables influence the dependent variable. Hence, brand loyalty is the dependent variable, and the product's attributes are the independent variable.

\section{Product's attributes and brand loyalty main hypothesis:}

$\boldsymbol{H}$ 1: There is significant relationship between product's attributes and brand loyalty H1a: There is a significant relationship between a product's physical attributes and brand loyalty.

H1b: There is a significant relationship between a product's value attributes and brand loyalty.

\section{Customer' satisfaction with brand loyalty}

The hypothesis to be tested for the relationship between customer's satisfaction and building brand loyalty goes as follow:

\begin{abstract}
H2: Customer's satisfaction has a mediating relationship between a product's attributes and brand loyalty.
\end{abstract}

\section{Methodology}

The main goal of this paper is to use a research methodology that discourses the hypothesis stated above and to answer the research questions about products attributes, stressing the dimension of physical product attributes, value-related product attributes and customer satisfaction in specific electronic appliances (SmartBuy) headquarters in Amman city, Jordan. The methodology used to collect information on customer satisfaction in these stores is through a questionnaire completed on a sample of general user population.

\subsection{Research Population and Sample}

The population included all the individual customers of two of the branches from (SmartBuy) in Amman. We designed the questionnaire and used simple random sampling for 150 respondents from the two selected branches.

\subsection{Validity}

To check the questionnaire for clarification and to present a solid research questionnaire, a deep review that went through and covered all the research structure was carefully completed by academic reviewers from the university of Jordan in Amman and took their comments and opinions, to make the required modifications, moreover, some of the paragraphs and questions were redesigned.

\subsection{Reliability}

The stability of the instrument of study calculated using the equation of internal consistency by test Cronbach's alpha as you can see in table 2 below, higher than (60\%) for all variables and identification of generally of the study of Cronbach alpha found which is acceptable level in the research and studies, and gives reliability coefficient between $(0.95-0.98)$ for the questionnaire as a whole as you can see in Table 1. 
Table 1: Cronbach's alpha for the study fields

\begin{tabular}{|l|c|}
\hline Variables & Cronbach Alpha \\
\hline Product attributes & 0.95 \\
\hline Customer satisfaction & 0.98 \\
\hline Brand loyalty & 0.96 \\
\hline All Questions & 0.98 \\
\hline
\end{tabular}

Source: Authors own computation

\subsection{Data Collection Method}

After distributing 150 surveys to respondents, only 107 of them were returned completed, and we excluded the other 43 questionnaires from the analysis because they did not have a fully completed information. So, with the (107) valid questionnaires for analysis the response rate was $(71.3 \%)$, and the demographic characteristics of the sample of the study can be seen in Table 2 below.

Table 2: The sample demographic Characteristics

\begin{tabular}{|l|c|c|}
\hline & Sample \\
\hline The gender & Frequency & Ratio \% \\
\hline (Male) & 64.5 & 69 \\
\hline (Female) & 35.5 & 38 \\
\hline Total & 107 & 100.0 \\
\hline Age & & \\
\hline Less than 20 years & 3 & 2.8 \\
\hline 20- less than 30 years & 83 & 77.6 \\
\hline 30- less than 40 years & 19 & 17.8 \\
\hline 40- less than 50 years & 2 & 1.9 \\
\hline More than 50 years & - & - \\
\hline Total & 107 & 100.0 \\
\hline
\end{tabular}

Source: Authors own computation

We applied a quantitative research approach and used SPSS to make sure that the related issues are covered and investigated in a comprehensive way. We relied on data collection of the questionnaire and the study sample responses; the questionnaire consists of two sections as follow:

- $\quad$ First part: Demographic variables concerning the customers and we used closed-ended questions (gender, age, average income/month and marital status).

- $\quad$ Second part: Contained 3 parts:

- Independent variable: Product's attributes which consisted of the following elements: (physical product attributes, value related attributes)

- Mediating variable: Customer satisfaction which consisted of the following elements: (product, Delivery, staff, service efficiency, And value of money.)

- Dependent variable: Brand loyalty which consisted of the following elements: (switching cost, positive past-experience and trust, commitment, and repeated purchases.)

It measures the attributes of products and the consumer's satisfaction dimensions and brand loyalty levels by using the five-point Likert-scale (Strongly agree $=5$, Agree $=4$, Neither agree nor disagree $=3$, Disagree $=2$, Strongly disagree $=1$ ). We adapted the questions of the 
questionnaire from previous studies and as you can see the distribution of items relating to each variable has been given in Table 3.

Table 3: Detail of Items

\begin{tabular}{|c|c|c|}
\hline Customer Satisfaction & Items number & Previous Studies \\
\hline Product & 4 Items & \multirow{5}{*}{$\begin{array}{l}\text { (Ali, F., et el.2015; Cronin, et } \\
\text { el 2000) }\end{array}$} \\
\hline Staff & 4 Items & \\
\hline Delivery & 3 Items & \\
\hline Service Efficiency & 6 Items & \\
\hline Value of Money & 4 Items & \\
\hline \multicolumn{3}{|l|}{ Brand Loyalty } \\
\hline Switching Cost & 4 Items & \multirow{5}{*}{$\begin{array}{l}\text { (Zeithaml, et el 1996; } \\
\text { Sirdeshmukh, et al 2002) }\end{array}$} \\
\hline Positive Past-experience and Trust & 3 Items & \\
\hline Commitment & 1 Item & \\
\hline Involvement & 2 Items & \\
\hline Repeated Purchases & 1 Item & \\
\hline \multicolumn{3}{|l|}{ Product's Attributes } \\
\hline Physical attributes & 9 Items & \multirow{2}{*}{$\begin{array}{l}\text { (Ekinci, et al 2001; } \\
\text { Madanoglu et al 2004) }\end{array}$} \\
\hline Value Attributes & 5 Items & \\
\hline
\end{tabular}

Source: Authors own computation

\section{Data Analysis and Findings}

According to the research purpose and framework mentioned and presented before, in this paper we will show a description of the results of the statistical analysis collected through the questionnaires to answer the research questions and research hypothesis, hence, the analysis contains a description of the Means and Standard Deviations of the research questions, in addition, Simple Regression, and ANOVA test was used.

\subsection{Descriptive Analysis of Study Variables}

\section{Level of importance (Products attributes)}

As you can see in table (4) we used four dimensions (arithmetic mean, standard deviation, item importance and importance level).

Table 4: Arithmetic mean, SD, item importance and importance level of products attributes

\begin{tabular}{|c|c|c|c|c|c|}
\hline No & Dimension & Mean & $\begin{array}{c}\text { Std. } \\
\text { Deviation }\end{array}$ & $\begin{array}{c}\text { Item } \\
\text { Importance }\end{array}$ & $\begin{array}{c}\text { Importance } \\
\text { Level }\end{array}$ \\
\hline 1 & $\begin{array}{c}\text { Physical Product } \\
\text { Attributes }\end{array}$ & 3.11 & 1.04 & 1 & Medium \\
\hline 2 & Value Related Attributes & 2.95 & 1.03 & 2 & Medium \\
\hline \multicolumn{2}{|c|}{ Total of Products A } & 3.03 & 1.01 & & Medium \\
\hline
\end{tabular}

Source: Authors own computation

As we can notice clearly from Table 4 the mean of this dimension (Products attributes), was among (3.11-2.95), meanwhile all dimension got a total mean of (3.03), which is considered as a level of Medium. And this tells us that most of the respondents have agreed on the importance of products attributes.

Both Dimensions (Product attributes) and (Value attributes) were considered as a level of Medium importance for the respondents. 


\section{Level of importance (Customer satisfaction)}

In Table 5 below, we used also the same four dimensions (arithmetic mean, standard deviation, item importance and importance level).

Table 5: Arithmetic mean, SD, item importance and Importance level of customer satisfaction

\begin{tabular}{|c|l|c|c|c|c|}
\hline No & \multicolumn{1}{|c|}{ Dimension } & Mean & $\begin{array}{c}\text { Std. } \\
\text { Deviation }\end{array}$ & $\begin{array}{c}\text { Item } \\
\text { Importance }\end{array}$ & $\begin{array}{c}\text { Importance } \\
\text { Level }\end{array}$ \\
\hline 2 & Delivery & 3.58 & 1.16 & 1 & Medium \\
\hline 3 & Staff & 3.48 & 1.16 & 2 & Medium \\
\hline 5 & Value of money & 3.44 & 1.22 & 3 & Medium \\
\hline 1 & Product & 3.35 & 1.24 & 4 & Medium \\
\hline 4 & Service efficiency & 3.18 & 1.05 & 5 & Medium \\
\hline \multicolumn{2}{|c|}{ Total } & 3.41 & 1.11 & & Medium \\
\hline
\end{tabular}

Source: Authors own computation

As you can see in table 5 above that the mean of this dimension (Customer satisfaction) was between $(3.58-3.18)$ and that showed how the customer satisfaction is important for the respondents.

The rank of the importance of the dimensions you can see above the (Delivery) got the maximum mean with (3.58), and (Service efficiency) came last it got a mean (3.18) and standard deviation (1.05) level of Medium.

This explains that customer Satisfaction with all dimensions are important for Customers.

\section{Level of importance (Brand loyalty)}

In Table 6 as before we used the dimension's arithmetic mean, standard deviation, item importance and importance level.

Table 6: Arithmetic mean, SD, item importance and importance level of Irand loyalty

\begin{tabular}{|c|l|c|c|c|c|}
\hline No & \multicolumn{1}{|c|}{ Dimension } & Mean & $\begin{array}{c}\text { Std. } \\
\text { Deviation }\end{array}$ & $\begin{array}{c}\text { Item } \\
\text { Importance }\end{array}$ & $\begin{array}{c}\text { Importance } \\
\text { Level }\end{array}$ \\
\hline 2 & $\begin{array}{l}\text { Positive Past-experience } \\
\text { and Trust }\end{array}$ & 3.39 & 1.13 & 1 & Medium \\
\hline 4 & Repeated Purchases & 3.33 & 1.26 & 2 & Medium \\
\hline 3 & Commitment & 3.31 & 1.19 & 3 & Medium \\
\hline 1 & Switching Cost & 3.16 & 1.16 & 4 & Medium \\
\hline Total & $\mathbf{3 . 3 0}$ & $\mathbf{1 . 1 1}$ & & Medium \\
\hline
\end{tabular}

Source: Authors own computation

This table shows that on the other previous variable (Brand loyalty) the respondents agreed that it is important for them, as can be seen in the results, that the mean of this variable was among (3.39 - 3.16) and that is considered as the level of Medium. Moreover, all the Dimensions of brand loyalty got a mean of more than 3 and that confirmed again how important these dimensions are for the respondents, as shown in the results above.

\subsection{Hypothesis Testing}

\subsubsection{Product's attributes and brand loyalty}

H1: There is a relationship between Product's Attributes (physical product attributes, value related attributes) and brand loyalty 
Oradea Journal of Business and Economics, Volume IV, Special Issue

Published on May 2019

Multiple regression analysis was used to test this hypothesis to ensure the relationship between Products Attributes (product attributes, value attributes) and brand loyalty as you can see in Table 7.

Table 7: Multiple Regressions

\begin{tabular}{|c|c|c|c|c|}
\hline \multicolumn{3}{|c|}{ Model Summary } \\
\hline Model & $\mathbf{R}$ & R Square & $\begin{array}{c}\text { Adjusted R } \\
\text { Square }\end{array}$ & Std. Error of the Estimate \\
\hline 1 & $.928^{\mathrm{a}}$ & .860 & .858 & .42051 \\
\hline
\end{tabular}

a. Predictors: (Constant), Value Attributes, Product Attributes

\begin{tabular}{|c|c|c|c|c|c|c|}
\hline \multicolumn{7}{|c|}{ ANOVA $^{\text {D }}$} \\
\hline \multicolumn{2}{|c|}{ Model } & Sum of Squares & df & Mean Square & F & Sig. \\
\hline \multirow{3}{*}{1} & Regression & 113.346 & 2 & 56.673 & 320.490 & $.000^{\text {a }}$ \\
\cline { 2 - 8 } & Residual & 18.391 & 104 & .177 & & \\
\cline { 2 - 8 } & Total & 131.737 & 106 & & & \\
\hline
\end{tabular}

a. Predictors: (Constant), Value Attributes, Product Attributes

b. Dependent Variable: Brand Loyalty

\begin{tabular}{|c|c|c|c|c|c|c|}
\hline \multicolumn{7}{|c|}{ Coefficients $^{a}$} \\
\hline \multirow{2}{*}{\multicolumn{2}{|c|}{ Model }} & \multicolumn{2}{|c|}{$\begin{array}{l}\text { Unstandardized } \\
\text { Coefficients }\end{array}$} & \multirow{2}{*}{$\begin{array}{c}\begin{array}{c}\text { Standardized } \\
\text { Coefficients }\end{array} \\
\text { Beta }\end{array}$} & \multirow[t]{2}{*}{$t$} & \multirow[t]{2}{*}{ Sig. } \\
\hline & & $B$ & Std. Error & & & \\
\hline \multirow[t]{3}{*}{1} & (Constant) & .226 & .130 & & 1.745 & .084 \\
\hline & Physical Product_Attributes & 1.102 & .096 & 1.027 & 11.488 & .000 \\
\hline & Value_Attributes & -.119 & .097 & $-.110-$ & $-1.232-$ & .221 \\
\hline
\end{tabular}

a. Dependent Variable: Brand_Loyalty

Source: Authors own computation

It is clear in Table 7 above, that the variable Products Attributes has a strong impact on the brand loyalty as you can notice the results of $R$ and $R$ square, and at the same time the results showed that (Physical Product Attributes) have a stronger relationship with brand loyalty, reaching $(t)$ calculated values (11.488), which value significant at the level of ( $\alpha$ $\geq 0.05$ ), meanwhile (Value related Attributes) have not shown any relationship between (Value related Attributes) and brand loyalty (t) values was $(-1.232)$ which value not significant at the level of $(\alpha \geq 0.05)$.

But in general and taking into account all the results above we can confirm the hypothesis that there is a relationship between Product's Attributes and brand loyalty.

H1a: There is relationship between a product's physical attributes and brand loyalty.

To test this hypothesis, the researcher uses the simple regression analysis to ensure the relationship between product's physical attributes and brand loyalty, as you see in Table 8 .

Table 8: The Simple regression to check the relationship between a product's physical attributes and brand loyalty

\begin{tabular}{|c|c|c|c|c|c|c|}
\hline $\mathbf{R}$ & $\mathbf{R 2}$ & B & Beta & F Value & DF & Sig \\
\hline 0.926 & 0.858 & 0.994 & 0.926 & 636.326 & 106 & $0.00^{*}$ \\
\hline
\end{tabular}


Source: Authors own computation

From Table 8 it is observed that there is a relationship between a product's physical attributes and brand loyalty. $R$ value was $(0.926)$, whereas the $R 2$ was $(0.858)$. That means that the $(85.8 \%)$ of product's physical attributes influence brand loyalty. As Beta was $(0.926)$ Assuring $F$ value was (636.326) and it is significant at level ( $\alpha \leq 0.05)$, that assures confirmed the hypothesis, and Figure 2 shows that:

Normal P-P Plot of Regression Standardized Residual

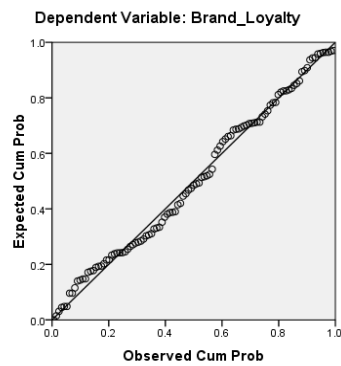

Figure 2: Regression plot to show the relationship between a product's physical attributes and brand loyalty.

Source: Authors own computation

H1b: There is relationship between a product's value attributes and brand loyalty.

Simple regression analysis used to test this hypothesis to ensure the relationship between product's value attributes and brand loyalty as shown in Table 9.

Table 9: Simple regression to ensure the relationship between a product's Value attributes and brand loyalty

\begin{tabular}{|c|c|c|c|c|c|c|}
\hline $\mathbf{R}$ & $\mathbf{R 2}$ & $\mathbf{B}$ & Beta & F Value & DF & Sig \\
\hline 0.827 & 0.683 & 0.897 & 0.827 & 226.480 & 106 & $0.00^{*}$ \\
\hline
\end{tabular}

Source: Authors own computation

From table (9) it is observed that there is a relationship between a product's value attributes and brand loyalty. The $\mathrm{R}$ was 0.827 , whereas the $\mathrm{R} 2$ was 0.683 . That means $68.3 \%$ of product's value attributes effects brand loyalty. Also, Beta came with 0.827 with $\mathrm{F}$ value 226.480 and it is significant at level $\alpha \leq 0.05$, and that confirms the hypothesis but showed that product's Value attributes has less effect on brand loyalty than physical attributes.

Normal P-P Plot of Regression Standardized Residual

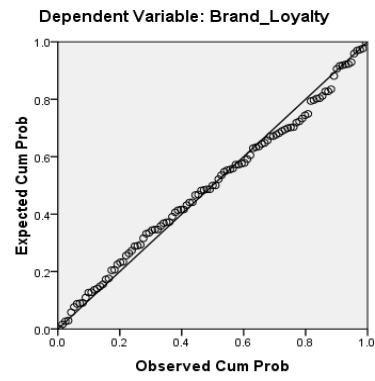

Figure 3: Simple regression plot to show the relationship between a product's value attributes and brand loyalty. 
Oradea Journal of Business and Economics, Volume IV, Special Issue

Published on May 2019

Source: Authors own computation

\subsubsection{Customer's satisfaction and brand loyalty}

The hypothesis to be tested for the relationship between customer satisfaction and building brand loyalty goes as follow:

H2: Customer's satisfaction has mediating relationship between a product's attributes and brand loyalty.

To test this hypothesis, the researcher uses the regression test and select the $\mathrm{R} 2$ Change and $(F)$ change value as shown in Table 10.

Table 10: Multiple regressions

\begin{tabular}{|c|c|c|c|c|c|c|c|c|c|}
\hline \multicolumn{9}{|c|}{ Model Summary } \\
\hline Model & $\mathbf{R}$ & R Square & $\begin{array}{c}\text { Adjusted R } \\
\text { Square }\end{array}$ & $\begin{array}{c}\text { Std. Error } \\
\text { of the } \\
\text { Estimate }\end{array}$ & $\begin{array}{c}\text { R } \\
\text { Square } \\
\text { Change }\end{array}$ & $\begin{array}{c}F \\
\text { Change }\end{array}$ & $\begin{array}{c}\text { df } \\
1\end{array}$ & df2 & $\begin{array}{c}\text { Sig. F } \\
\text { Change }\end{array}$ \\
\hline 1 & $.905^{\mathrm{a}}$ & .818 & .815 & .47960 & .818 & 234.361 & 2 & 104 & .000 \\
\hline
\end{tabular}

a. Predictors: (Constant), Total of Customer Satisfaction, Total Products Attributes

\begin{tabular}{|l|l|c|c|c|c|c|}
\hline \multicolumn{2}{|c|}{ ANOVA $^{\text {d }}$} \\
\hline \multirow{2}{*}{ Model } & $\begin{array}{c}\text { Sum of } \\
\text { Squares }\end{array}$ & df & $\begin{array}{c}\text { Mean } \\
\text { Square }\end{array}$ & F & Sig. \\
\cline { 2 - 7 } & Regression & 107.815 & 2 & 53.907 & 234.361 & $.000^{\mathrm{a}}$ \\
\cline { 2 - 8 } & Residual & 23.922 & 104 & .230 & & \\
\cline { 2 - 8 } & Total & 131.737 & 106 & & & \\
\hline
\end{tabular}

a. Predictors: (Constant), Total of Customer Satisfaction, Total Products Attributes

b. Dependent Variable: Brand Loyalty

\begin{tabular}{|c|c|c|c|c|c|c|}
\hline \multicolumn{7}{|c|}{ Coefficients $^{a}$} \\
\hline \multirow{2}{*}{\multicolumn{2}{|c|}{ Model }} & \multicolumn{2}{|c|}{$\begin{array}{l}\text { Unstandardized } \\
\text { Coefficients }\end{array}$} & \multirow{2}{*}{$\begin{array}{c}\text { Standardized } \\
\text { Coefficients } \\
\text { Beta }\end{array}$} & \multirow{2}{*}{$\mathbf{t}$} & \multirow{2}{*}{ Sig. } \\
\hline & & $\mathrm{B}$ & Std. Error & & & \\
\hline \multirow[t]{3}{*}{1} & (Constant) & .166 & .154 & & 1.078 & .283 \\
\hline & Total_Products_Attributes & .784 & .085 & .711 & 9.193 & .000 \\
\hline & Total_of_Customer_Satisfaction & .221 & .077 & .221 & 2.860 & .005 \\
\hline
\end{tabular}

a. Dependent Variable: Brand Loyalty

Source: Authors own computation 


\section{Discussion}

The results show that customer's satisfaction has a mediating relationship between product's attributes and brand loyalty, and this confirms how important customer satisfaction is for the company's relationship with its customer and for keeping their loyalty. In addition, we can notice from the results that $\mathrm{R} 2$ change was (81.8\%), (F) change was (234.361) and its significant at $(0.05)$ level. This means that the percentage of customer satisfaction reached $81.8 \%$ based on the relationship between brand loyalty and products attributes. Finally, and based on the significant relationships between the variables showed during the analyses, we can reassure that all the hypothesis we mentioned earlier can be confirmed (see Table 11).

Table 11: Hypothesis Test

\begin{tabular}{|l|l|c|}
\hline H1 & $\begin{array}{l}\text { There is relationship between product's attributes and } \\
\text { brand loyalty }\end{array}$ & Supported \\
\hline H1a & $\begin{array}{l}\text { There is relationship between a product's physical } \\
\text { attributes and brand loyalty. }\end{array}$ & Supported \\
\hline $\mathbf{H 1 b}$ & $\begin{array}{l}\text { There is relationship between a product's value attributes } \\
\text { and brand loyalty. }\end{array}$ & Supported \\
\hline $\mathbf{H 2}$ & $\begin{array}{l}\text { Customer's satisfaction has mediating relationship } \\
\text { between a product's Attributes and brand loyalty. }\end{array}$ & Supported \\
\hline
\end{tabular}

Source: Authors own computation

\section{Conclusion}

The results of the data analysis that we have conducted suggest that there is a correlation between the variables in the situation of the company that we chose in the electronic appliances industry sector in Jordan; however more extensive researches in terms of the number of companies used in sampling must be conducted to verify this relation.

Some of our findings are that customer satisfaction does not seem to be a basic variable as it is composed of several partial elements that affect the firm and its performance in a complex manner. Additionally, the influence of this element is reflected on different time interludes, so the complexity of their effect can best be observed over a long period of time. This finding is considered to be very important as the main aim for the firms is usually to maintain long-term performance and this can only be done by ensuring future satisfaction of the customers as well as the immediate one.

The relationship between customer satisfaction and brand loyalty is widely tested and proven by many studies, and our study reassured the strong relationship between the variables previously mentioned. Therefore, brand loyalty is very important and essential for a firm's survival in the long-run.

For companies to fulfil their customer's needs and to ensure their current and long-run satisfactions, firms have to offer differentiated high-quality products as well as differentiated service offerings. And so, further research needs to be done to examine all possible factors affecting long-term customer's satisfaction which will eventually turn into brand loyalty and try to do more practical researches in a different type of organizations and different sectors.

\section{References}

Abdul Ghafoor, A. and Asad-ur, R., 2014. Impact of Customer Satisfaction on Brand LoyaltyAn Empirical Analysis of Home Appliances in Pakistan, British Journal of Marketing Studies, 2 (8), pp. 18-32. 
Ali, F., and Muqadas, S., 2015. The Impact of Brand Equity on Brand Loyalty: The Mediating Role of Customer Satisfaction, Pakistan Journal of Commerce and Social Sciences, 9 (3), pp. 890-915.

Blattberg, R.A. and Deighton, J. 1996. Manage Marketing by the Customer Equity Test. Harvard Business Review, July-August, pp.136-144.

Bloemer, J. M., and Kasper, H. D., 1995. The Complex Relationship between Consumer Satisfaction and Brand Loyalty. Journal of Economic Psychology, 16 (2), pp. 311-329.

Cronin, J. J., Brady, M. K., and Hult, G. T. M., 2000. Assessing the effects of quality, value, and customer satisfaction on consumer behavioral intentions in service environments. Journal of Retailing, 76 (2), pp. 193-218.

Delgado-Ballester, E., and Luis Munuera-Alemán, J., 2003. Brand trust in the context of consumer loyalty. European Journal of Marketing, 35 (11/12), pp. 1238-1258.

Dhurup, M., Mafini, C., and Dumasi, T., 2014. The impact of packaging, price and brand awareness on brand loyalty: Evidence from the paint retailing industry. Acta Commercii, 14(1), Art. \#194, 9 pages. http://dx.doi.org/10.4102/ac.v14i1.194.

Edvardsson, B., Johnson, M. D., Gustafsson, A., and Strandvik, T., 2002. The effects of satisfaction and loyalty on profits and growth: Products versus services. Total Quality Management, retrieved from Cornell University, School of Hospitality Administration site: http://scholarship.sha.cornell.edu/articles/714, 11 (7), pp. 917-927.

Ekinci, Y. 2001. The validation of the generic service quality dimensions: An alternative approach. Journal of Retailing and Consumer Services, 8 (6), pp. 311-324.

Fites, D. V., 1996. Make your dealers your partners, Harvard Business Review, March-April, pp. 84 - 95.

Fournier, S. and Glick, D. G., 1999. Rediscovering satisfaction. Journal of Marketing, 63 (4), pp. 5-23.

Gómez, M. I., McLaughlin, E. W., and Wittink, D. R., 2004. Customer satisfaction and retail sales performance: An empirical investigation. Journal of Retailing, 80, pp. 265-278.

Jacoby, J., 1971. Brand loyalty: A conceptual definition. American Psychological Association, 6 (July), pp. 655-656.

Kotler, P., and Zeithaml, V., 2000. Marketing Management, Millenium Edition. Marketing Management, 23 (6), pp. 188-193. https://doi.org/10.1016/0024-6301(90)90145-T

Kotler, P., Armstrong, G., Wong, V. and Saunders, J., 2008. Principles of marketing. 5th ed. Harlow: Pearson.

Madanoglu, M., 2004. Validating restaurant service quality dimensions. Journal of Foodservice Business Research, 7 (4), pp. 127-147.

Oliver, R.L., 1981. Measurement and Evaluation of Satisfaction Processes in Retail Settings. Journal of Retailing, 5, pp. 25-48.

Oliver, R.L., 1997. Satisfaction: A Behavioral Perspective on the Consumer. New York: The McGraw-Hill Companies, Inc.

Pakurár, M. Haddad, H., Nagy, J., Popp, J., Oláh, J., 2019 The Service Quality Dimensions that Affect Customer Satisfaction in the Jordanian Banking Sector, Sustainability, 11, 1113; doi:10.3390/su11041113.

Piercy, N. F., 1995. Customer satisfaction and the internal market Marketing our customers to our employees. Journal of Marketing Practice, 1 (1), pp. 22-44.

Reichheld, F.F., 1996. The Loyalty Effect. Boston: Harvard Business School Press.

Shaharudin, M. R., Hassan Abu, A., Mansor, S. W., Elias, S. J., Harun, E. H., and Aziz, N. A., 2010. The Relationship between Extrinsic Attributes of Product Quality with Brand Loyalty on Malaysia National Brand Motorcycle / Scooter. Canadian Social Science, 6 (3), pp. 165-175.

Sirdeshmukh, D., Singh, J., and Sabol, B., 2002. Consumer trust, value, and loyalty in relational exchanges. Journal of Marketing, 66 (1), pp. 15-37. 
Spreng, R. A., MacKenzie, S. B., and Olshavsky, R. W., 2006. A Reexamination of the Determinants of Consumer Satisfaction. Journal of Marketing, 60 (3), 15-32.

Zeithaml, V. A., Berry, L. L., and Parasuraman, A., 1996. The behavioral consequences of service quality. The Journal of Marketing, 60 (2), pp. 31-46.

\section{Bio-note}

Aburumman Nemer is a PhD student in the University of Debrecen / Applied Informatics and Logistics Institute and member of the several research teams developed within the projects implemented by our Faculty. As a PhD student, Aburumman focused on the use of technology in the public sector administration (e-government, e-agriculture etc.).

Nieto Asisa (Mrs), is a researcher finished her bachelor at Pablo de Olavide University Sevilla, Spain. Nieto is a member of the several research teams developed within the projects implemented by some organization. As a researcher, Nieto focused on Marketing, public administration, and linguistic studies. 